Niepełnosprawność. Dyskursy pedagogiki specjalnej

Nr 29/2018

Disability. Discourses of special education

No. $29 / 2018$

Mirosław Rutkowski, Karol Bidziński

Uniwersytet Jana Kochanowskiego w Kielcach

\title{
Szkoła ogólnodostępna przestrzenią spotkania nauczycieli i pedagogów specjalnych - realizatorów idei edukacji włączającej
}

Współczesny system edukacji stawia wobec specjalistów z zakresu pedagogiki specjalnej wymagania znacznie bardziej złożone niż te, które wiązały się z tą specjalnością w przeszłości. Oczekuje od nich nie tylko wykonywania działań edukacyjnych i terapeutycznych z uczniem w szkole specjalnej, ale także umiejętności współtworzenia przestrzeni społecznej sprzyjającej realizacji potrzeb uczniów w zróżnicowanych środowiskach edukacyjnych. Jednym z takich środowisk jest szkoła ogólnodostępna, w której dochodzi do spotkania pracujących w niej nauczycieli ze specjalistami z zakresu pedagogiki specjalnej. W artykule poszukiwano odpowiedzi na pytanie, w jakich warunkach pedagogika specjalna ze swoim dorobkiem teoretycznym i praktycznym może stać się źródłem wartościowych inspiracji dla nauczycieli szkół ogólnodostępnych rozwiązujących problemy wynikające $z$ indywidualnych potrzeb rozwojowych i edukacyjnych uczniów z niepełnosprawnością.

Słowa kluczowe: przestrzeń edukacyjna, specjalne potrzeby edukacyjne wynikające z niepełnosprawności, szkoła ogólnodostępna, specjaliści z zakresu pedagogiki specjalnej, wsparcie dla nauczycieli

\section{Mainstream school as a meeting space of teachers and special educators - promoting the idea of inclusive education}

In the contemporary education system, special education professionals meet much more complex requirements than in the past. They are expected to perform educational and therapeutic activities with students at special school, as well as to be able to co-create social space that meets the needs of students in different learning environments. One of these environments is a public, mainstream school, where teachers need to collaborate with special education professionals. The article aims to answer the question: in what way can special education and its theoretical and practical resources become a valuable source for teaching practices for mainstream school teachers? How can teachers and special education professionals work together to face and solve problems while working with special - education students whose individual developmental and educational needs result from disability?

Keywords: educational space, special educational needs, mainstream school, special education professionals, support for teachers 


\section{Wprowadzenie}

Obserwowana od kilkunastu lat coraz powszechniejsza obecność w przestrzeni edukacyjnej ${ }^{1}$ szkoły ogólnodostępnej uczniów z niepełnosprawnością, otwiera tę szkołę na kontakt z teorią i praktyką pedagogiki specjalnej oraz stwarza okazję do częstych zawodowych spotkań nauczycieli z różnymi specjalistami posiadającymi kwalifikacje z zakresu pedagogiki specjalnej. $W$ takich okolicznościach pedagogika specjalna, ze swoim dorobkiem teoretycznym i praktycznym, może stać się źródłem wartościowych inspiracji dla nauczycieli szkół ogólnodostępnych poszukujących rozwiązania problemów napotykanych w pracy z uczniami, których indywidualne potrzeby rozwojowe i edukacyjne wynikają m.in. z niepełnosprawności. Od pedagogów specjalnych oczekuje się wsparcia procesów inkluzyjnych przez dokonanie transferu teorii pedagogicznej i rozwiązań metodycznych z przestrzeni szkoły specjalnej i specjalistycznych gabinetów terapeutycznych do środowiska szkoły ogólnodostępnej. Interesujące jest w jakim stopniu współcześni pedagodzy specjalni przygotowani są do realizacji tego zadania? Czy będą gotowi, ryzykując chwilową utratę poczucia bezpieczeństwa, dokonać trudnej rekonstrukcji własnej tożsamości zawodowej? Na ile szkoła ogólnodostępna i pracujący w niej nauczyciele oczekują wsparcia od pedagogów specjalnych i potrafią przyjąć to wsparcie? W jakich warunkach możliwe będzie wzmocnienie edukacyjnych procesów inkluzyjnych poprzez współdziałanie pedagogów specjalnych i nauczycieli szkół ogólnodostępnych?

Przestrzeń mentalną spotkania nauczycieli i pedagogów specjalnych wyznacza, przyjęta do realizacji na początku lat $90 . X_{X}$ w., idea budowania szkoły dostępnej dla wszystkich, której podstawowe zasady zapisano w programie Światowej Deklaracji Edukacja dla Wszystkich (Education for All) [1990]. Idea ta znajduje także wyraz w kolejnych dokumentach: Standardowych Zasadach Wyrównywania Szans Osób Niepełnosprawnych [1990], Deklaracji z Salamanki [1994], Konwencji o Prawach Osób Niepełnosprawnych [2006]. Początkowo realizacja postulatów zawartych w przywołanych dokumentach przebiegała głównie poprzez urzeczywistnianie idei normalizacyjnych i integracyjnych, dzisiaj przybiera także formę edukacji włączającej.

1 Przestrzeń edukacyjna to termin od dawna stosowany w pedagogice - zob. B. Dymara (1998), Przestrzenie szkoty i przestrzenie życia, czyli trzy światy dziecka [w:] Dziecko w świecie szkoty, red. B. Dymara, Oficyna Wydawnicza „Impuls”, Kraków; A. Nalaskowski (2002), Przestrzeń i miejsce szkoty, Oficyna Wydawnicza „Impuls”, Kraków. Interesującą próbę wyjaśnienia pojęcia, opisania istoty i przedstawienia właściwości przestrzeni edukacyjnej podjęła I. Surina (2012), Rozważania o przestrzeni edukacyjnej - od teorii do praktyki edukacyjnej [w:] Przestrzeń edukacyjna wobec wyzwań wspótczesności, red. I. Surina, Oficyna Wydawnicza „Impuls”, Kraków. 
Podczas wdrażania idei budowania szkoły dostępnej dla wszystkich pojawia się wiele szczegółowych dylematów oraz obszarów interesujących dla analiz naukowych. Są to zarówno kwestie natury zasadniczej, jak i problemy formalnoprawne, organizacyjne i techniczne. Podstawowy problem stanowi rozstrzygnięcie dylematu: które koncepcje wypracowane w ramach pedagogiki specjalnej, jej teorii i praktyki, są wartościowe i przydatne w nowej rzeczywistości edukacyjnej? Które koncepcje straciły swą aktualność, a być może są i takie, które w nowych warunkach są nie tylko mało efektywne, ale wręcz niebezpieczne dla praktyki pedagogicznej? Współczesna pedagogika specjalna głosem swoich teoretyków dokonuje oceny dotychczasowego dorobku naukowego oraz swoistego wewnętrznego przewartościowania [Krause 2010; Chrzanowska 2015]. Przejawem tych przemian jest krytyka tradycyjnego modelu medycznego oraz osadzenie współczesnej pedagogiki specjalnej na paradygmacie humanistycznym, zwłaszcza subparadygmacie społecznym i tworzących go teoretycznych modelach: normalizacyjnym i upełnomocnienia. Amadeusz Krause [2013a i 2013b] zachęca, aby bez obaw o utratę własnej tożsamości naukowej w ramach pedagogiki specjalnej podjąć dialog z dorobkiem innych subdyscyplin pedagogicznych, a zwłaszcza pedagogiki krytycznej i emancypacyjnej, poszukując w nich inspiracji do badań i refleksji naukowej.

\section{Pedagogika specjalna - wobec "grzechu" biologicznego determinizmu w myśleniu o uczniu z niepełnosprawnością}

W przeszłości wśród działań kierowanych wobec osób z niepełnosprawnością dominowały czynności opiekuńcze i medyczne, z czasem pojawiły się postulaty rehabilitacyjne i edukacyjne. Działaniom praktycznym towarzyszyła refleksja teoretyczna, która z czasem stała się podstawą stworzenia pedagogiki specjalnej jako subdyscypliny pedagogiki. $\mathrm{W}$ początkowym okresie gromadzenia danych naukowych pedagodzy, wzorując się na naukach przyrodniczych, poszukiwali przyczyn różnych zjawisk dotyczących człowieka z niepełnosprawnością, odwołując się wyłącznie do racjonalności instrumentalnej. $W$ badaniach poszukiwano bezpośrednich zależności między stanem zdrowia biologicznego a funkcjonowaniem psychicznym, charakterem społecznych relacji, a także możliwościami edukacyjnymi osób z różnymi rodzajami niepełnosprawności. Przestrzeń naukowego dyskursu oraz praktyki pedagogicznej wypełniły paradygmat medyczny i zgodne z nim modele medyczny (biologiczny) i rehabilitacyjny. W ramach modelu medycznego niepełnosprawność była utożsamiana głównie jako odchylenie od biomedycznych norm i standardów struktury i funkcji organizmu. W modelu 
tym koncentrowano się przede wszystkim na biologicznym aspekcie funkcjonowania człowieka, a sytuacje doświadczania niepełnosprawności opisywano w postaci liniowej i bezwarunkowej zależności przyczynowo-skutkowej bez uwzględniania złożonych uwarunkowań kontekstowych. Krytycznego wartościowania tego modelu i jego wpływu na indywidualne i społeczne pojmowanie zjawiska niepełnosprawności dokonali m.in. J. Kirenko [2007], A. Krause [2010], I. Chrzanowska [2015].

W 1980 roku WHO zaproponowało Międzynarodową Klasyfikację Uszkodzeń, Niepełnosprawności i Upośledzeń, która wzorowana była na modelu dynamicznym. Zgodnie z tym modelem uszkodzenie utożsamiano ze stratą bądź wadą fizjologiczną, anatomiczną, psychiczną struktury lub czynności organizmu powodującą ograniczoną sprawność wykonywania czynności na poziomie uznawanym za normalny dla człowieka. Ta obniżona sprawność $\mathrm{w}$ dużym stopniu upośledza jednostkę, ograniczając jej społeczną aktywność, związaną z wypełnianiem ról społecznych [Majewski 1995]. Ponieważ dysfunkcję struktur anatomicznych lub fizjologicznych funkcji traktowano jako czynnik destrukcyjnie determinujący całokształt psychicznego i społecznego funkcjonowania człowieka, głównym celem oddziaływań uczyniono starania prowadzące do usunięcia tej biologicznej „niedoskonałości”. W sytuacjach, gdy odstępstwo od biologicznej normy było wyraźne, wprowadzono w przestrzeń socjalizacyjną człowieka intensywne działania rehabilitacyjne.

W modelu medycznym szczególne nadzieje wiązano z procesem terapii, który wyraźnie zaczął dominować nad oddziaływaniami edukacyjnymi, a zwłaszcza dydaktycznymi. Niemal wszystkie działania służące wspieraniu rozwoju człowieka wiązano $\mathrm{z}$ terapią, podobnie wszelkie pozytywne zmiany $\mathrm{w}$ jego społecznym funkcjonowaniu interpretowano jako rezultat skutecznych oddziaływań terapeutycznych. Był to czas, w którym hasło „terapia” stało się wspólnym mianownikiem dla wszelkich oddziaływań kierowanych wobec osób z niepełnosprawnością, nawet naturalnym, codziennym czynnościom nadawano walor terapeutyczny. W tym okresie edukacyjnie wartościowe oddziaływania nabierały mocy, jeśli "Wzbogacano" je o elementy terapii. I tak, naturalne dla rozwoju dziecka aktywności zmysłowego doświadczania świata nazwano terapią „doświadczania świata", kontakt dziecka z literaturą stawał się skuteczny, jeśli zamieniał się w proces biblioterapii, podobnie kontakt człowieka z przyrodą stawał się animaloterapią, silwoterapią. Wielu aspektom działalności człowieka doświadczającego niepełnosprawności nadawano znaczenie terapeutyczne: działania wytwórcze określono jako terapia zajęciowa, wykonywanie pracy to ergo-terapia, kontakt z dziełami sztuki oraz aktywność twórcza to arteterapia, muzykoterapia, choreoterapia, teatroterapia i inne. Inicjowaniu tego typu aktywności towarzyszyły nierzadko nadmierne oczekiwania związane $\mathrm{z}$ "naprawczym charakterem" tych oddziaływań. 
Wiele metod terapeutycznych nie zostało pozytywnie zweryfikowanych przez naukę. T. Witkowski [2009] w książce Zakazana psychologia dokonał daleko idącej krytyki niektórych metod psychoterapeutycznych stworzonych bez naukowych uzasadnień lub opartych na pseudo-nauce. Należy jednak pamiętać o tym, że obok niesprawdzonych technik istnieje wiele metod o charakterze terapeutycznym, które oparto na solidnych podstawach teoretycznych, a ich skuteczność znalazła potwierdzenie w badaniach weryfikacyjnych. Przed współczesnymi pedagogami specjalnymi stoi ważne zadanie dokonania naukowej weryfikacji stosowanych dotychczas metod terapeutycznych oraz wsparcie metodyków w opracowywaniu nowych rozwiązań praktycznych.

W działaniach praktycznych opartych na modelu medycznym zakładano, że jedynie specjalista posługujący się skomplikowanymi metodami terapeutyczny$\mathrm{mi}$, realizowanymi najlepiej także w specjalnie do tego celu stworzonym środowisku edukacyjnym - szkole specjalnej lub gabinecie terapeutycznym, jest pełnomocny do pracy z niepełnosprawnym uczniem. Mimo tego deterministycznego i dość uproszczonego $\mathrm{w}$ założeniach epistemologicznych sposobu analizowania sytuacji człowieka, niezaprzeczalnym dorobkiem tego okresu jest poznanie istoty oraz przyczyn wielu odmienności biologicznych ludzkiej egzystencji a w ślad za tym wypracowanie skutecznych sposobów zaspokajania wynikających z nich potrzeb rozwojowych i edukacyjnych, w tym metod i technik o charakterze terapeutycznym, a także rozwiązań metodycznych usprawniających proces nauczania - uczenia się (dydaktyka szkoły specjalnej). Siłą pedagogiki specjalnej był i nadal pozostaje jej interdyscyplinarny i pragmatyczny charakter oraz wynikająca z jej przedmiotu badań służebna rola wobec człowieka.

Z czasem na gruncie pedagogiki specjalnej i innych nauk społecznych uznano, że przyczyn trudności i ograniczeń doświadczanych przez człowieka w codziennym życiu, w tym także w sytuacjach uczenia się, należy poszukiwać nie tylko $\mathrm{w}$ jego właściwościach indywidualnych, ale także w sposobie organizacji środowiska społecznego.

Idee, pojawiające się w środowiskach działających na rzecz osób z niepełnosprawnościami, a także organizacjach emancypacyjnych osób doświadczających różnych rodzajów niepełnosprawności w latach 70. ubiegłego stulecia w Wielkiej Brytanii, zawierały założenia odwołujące się do szukania przyczyn niepełnosprawności nie w jednostce, lecz w ograniczającym ją, opresyjnym środowisku oraz społecznych, fizycznych i ekonomicznych barierach. Opierający się na tych założeniach i będący w opozycji do modelu medycznego model społeczny odchodzi od postrzegania niepełnosprawności w kontekście kategoryzowania ludzi i proponuje rozpatrywanie jej jako uniwersalne ludzkie doświadczenie. Główną strategią rozwiązań proponowanych w modelu społecznym jest inkluzja społeczna (w tym edukacyjna), a narzędziami działania - diagnoza potrzeb (związana 
z szacowaniem warunków ich realizacji), elastyczne zmiany w organizacji przestrzeni oraz projektowanie uniwersalne. Można zauważyć, że powyższe podejście zdejmuje z grupy osób z niepełnosprawnościami etykietę grupy mniejszościowej [Szluz 2007; Woźniak 2008; Wiliński 2010].

Przyjęcie inkluzji społecznej (w tym edukacyjnej) jako dominującej strategii społecznego modelu niepełnosprawności wraz z jej narzędziem - projektowaniem uniwersalnym (ang. Universal Design - UD) zakłada, iż osoby z niepełnosprawnościami mają większe szanse na włączenie i uczestniczenie w głównym nurcie życia społecznego, jeśli otoczenie, przestrzeń użytkowa i produkty planowane będą tak, aby mogli z nich korzystać wszyscy.

UD proponuje siedem elementarnych, a zarazem uniwersalnych zasad projektowania: równe szanse dla wszystkich, elastyczność w użyciu, prostota i intuicyjność obsługi, postrzegalność informacji, tolerancja błędu, niewielki wysiłek fizyczny podczas użycia, wystarczający rozmiar i przestrzeń użytkowania [Błaszak, Przybylski 2010; Budny 2004]. W przestrzeni edukacji włączającej oznacza to promowanie rozwiązań, pozwalających wszystkim uczniom realizować swoje różnorodne (w tym specjalne) potrzeby edukacyjne. Na początku XXI wieku fundament dla takich rozwiązań zaproponowany został przez F. Bowe [2000] w uniwersalnych zasadach projektowania strategii przekazu wiedzy (ang. Universal Instructional Design, UID): 1) dostępność, 2) elastyczność, 3) bezpośrednia i intuicyjna obsługa, 4) efektywne i przejrzyste metody przekazu wiedzy, 5) wspierające ucznia otoczenie, 6) minimalizowanie zbędnych zadań i wymagań, 7) odpowiednia przestrzeń. Zastosowano je $\mathrm{w}$ rozwijanej i wciąż aktualizowanej koncepcji projektowania uniwersalnego uczenia się/nauczania - UDL (ang. Universal Design for Learning) [CAST, 2011; Universal Design for Learning Guidelines].

UDL stanowi dziś solidną metodologiczną podstawę edukacji inkluzyjnej opartą o trzy zasadnicze standardy pozwalające optymalizować rozwój procesów poznawczych oraz instrumentalnych wszystkich uczniów:

1. zapewnieniu możliwości percepcji (wielokanałowość przekazu z możliwością wyboru odpowiedniego kanału, elastyczny format przekazu itp.);

2. zapewnieniu możliwości korzystania z adekwatnego kodu językowego, wyrażeń matematycznych i symboli (wyjaśnienie słownictwa, symboli, struktury składni, wspieranie dekodowania tekstu, zapisu matematycznego i symbolicznego, ilustrowanie za pomocą różnych mediów itp.);

3. zapewnieniu możliwości rozumienia (porządkowanie wiadomości, przystępne konstruowanie systemu wiedzy, zakotwiczanie pamięciowe wiedzy, instrukcje przetwarzania informacji, wizualizacja, mapy myśli itp.)

Pierwszy z wymienionych standardów dotyczy przede wszystkim procesu identyfikacji - rozpoznania treści uczenia się/nauczania („,zego się uczyć?”) i prezentowania informacji w zróżnicowany sposób. Drugi - odnosi się głównie do 
organizowania i różnorodności ekspresji treści („jak się uczyć?”). Trzeci zaś standard definiuje kwestie waloryzacji i motywacji uczenia się („po co się uczyć?”), określając w szczegółowych wytycznych sposoby wzbudzania zainteresowania i motywacji ${ }^{2}$.

Aktualnie model medyczny, podobnie jak model społeczny, ulega powolnej przemianie, czego przejawem jest współczesne, wielowymiarowe definiowanie zdrowia jako podstawowej kategorii pojęciowej dla tego modelu. „Respektując założenia współczesnej psychologii, że człowiek jest jednością czterech warstw swojej egzystencji: fizycznej, psychicznej, społecznej i duchowej (noetycznej), oraz definicji zdrowia według WHO, należy przyjąć, iż zdrowie człowieka ma cztery podstawowe wymiary wzajemnie na siebie wpływające: fizyczny, psychiczny, społeczny i duchowy" [Pilecka 2011, s. 20].

Niepełnosprawność nie jest traktowana wyłącznie w kategoriach choroby, defektu ciała oraz naruszenia jego sprawności, istotne są także pozostałe wymiary ludzkiego zdrowia. Wyrazem tych przemian są próby znalezienia kompromisu między dwoma tradycyjnymi już koncepcjami medycznego i społecznego modelu niepełnosprawności. Pierwszą próbą uwzględnienia tych dwóch punktów widzenia podczas opisywania zjawiska ludzkiej niepełnosprawności była Międzynarodowa Klasyfikacja Uszkodzeń, Niepełnosprawności i Upośledzeń (International Classification of Impairments, Disabilities and Handicaps, ICIDH) opracowana przez WHO w 1980 roku oraz zmieniona i uaktualniona jej edycja z 1998 roku (ICIDH-2) - nazwana przez jej twórców modelem uniwersalnym [Ustün 1999, s. 8]. Ostatnią propozycją jest model zawarty w Międzynarodowej Klasyfikacji Funkcjonowania, Niepełnosprawności i Zdrowia (International classification of functioning, disability and Heath, ICF), oraz wersja odnoszącą się do dzieci i młodzieży (International classification of functioning, disability and health: children $\mathcal{E}$ youth version ICF-CY). W tym interakcyjnym modelu niepełnosprawności funkcjonowanie jednostki w określonej dziedzinie jest postrzegane jako interakcja lub złożony wzajemny związek między stanem zdrowia (funkcje i struktury ciała), zakresem aktywności i uczestnictwa a czynnikami kontekstowymi (tzn. czynnikami środowiskowymi i osobowymi). Między czynnikami tymi zachodzi dynamiczna interakcja. To, czy i w jakim stopniu zakres i rodzaj uszkodzenia anatomicznej struktury ciała lub zaburzenia w jego funkcjonowaniu wpływają na aktywność osoby i jej społeczne funkcjonowanie, w dużym stopniu determinowane jest przez zasoby indywidualne oraz warunki środowiskowe. Do tego modelu odwołują się autorzy Konwencji o Prawach Osób Niepełnosprawnych, przyjętej w grudniu 2006 r. na sesji Zgromadzenia Ogólnego ONZ i ratyfikowanej przez

2 Zagadnienie to zaprezentowano w pracy: M. Rutkowski (2013), Niepetnosprawność w edukacji - nowe konteksty: przestrzeń - relacje - komunikacja [w:] Problematyka niepetnosprawności w mediach i edukacji, red. E. Jaska, T. Skoczek, Wydawnictwo SGGW, Warszawa. 
Polskę we wrześniu 2012 r. Przyjęcie tego modelu niepełnosprawności, z mocnym akcentowaniem kontekstu środowiskowego, pociąga za sobą daleko idące konsekwencje dla orzecznictwa oraz organizacji działań pomocowych.

Pedagogika specjalna, ze swoim bogatym dorobkiem teoretycznym i praktycznym, wyzwolona z grzechów biologicznego determinizmu, powoli staje się źródłem wartościowych inspiracji teoretycznych dla innych przedstawicieli nauk o wychowaniu oraz odniesień dla praktyki pedagogicznej. Dzięki antypozytywistycznemu przełomowi, który dokonał się w naukach społecznych oraz ukształtowaniu paradygmatu humanistycznego zmienił się sposób badania fenomenu niepełnosprawności oraz stosunek do osób z niepełnosprawnościami i praktyki organizacji ich przestrzeni życiowej, w tym szkolnej edukacji. Naukowcy uznali, że nie da się opisywać złożonych zjawisk społecznych i niepowtarzalności losów osoby ludzkiej, odwołując się jedynie do racjonalności ${ }^{3}$ kognitywno-instrumentalnej (porządek czynu). Niezbędne jest oparcie procesu badawczego na racjonalności komunikacyjnej, czyli prowadzenie dociekań naukowych w porządku rozumienia. Porządek ten wyznacza stawianie pytań egzystencjalnych, których celem jest zrozumienie sensu istnienia, własnego działania i innych poważnych ludzkich dylematów. Drogą do poznania indywidualnego doświadczenia egzystencjalnego i włączenia go do doświadczania wspólnoty sensu jest dialog prowadzony w duchu wspólpracy i krytycyzmu [Kwaśnica 2014].

Postulat ten najpełniej znajduje swój wyraz w pedagogice zorientowanej humanistycznie, w której szczególnego znaczenia nabiera refleksja hermeneutyczna i fenomenologiczny wgląd w świat ludzkich sensów i nadawanych znaczeń oraz próba ich jakościowych analiz/rekonstrukcji. Te i inne orientacje humanistyczne (np. heurystyka, interakcjonizm symboliczny, etnometodologia) tworzą solidną podstawę filozoficzno-metodologiczną uprawiania badań. Inspirujące są nurty współczesnych studiów humanistycznych (teoria krytyczna, studia kulturowe, studia ewaluacyjne i inne), które powstały dzięki przyjęciu transdyscyplinarnej perspektywy badawczej [Kubinowski 2010, s. 26-48].

Pedagogika specjalna może wiele czerpać $\mathrm{z}$ dorobku pedagogiki zorientowanej humanistycznie, ale też wiele wnosić do jej dalszego rozwoju. Łączy je bowiem, z jednej strony, swoisty idealizm - wiara w misyjną i uzdrawiającą moc nauki, a z drugiej, pragmatyzm - podkreślanie użyteczności działalności naukowej i aktywnego udziału badacza w zmienianiu otaczającego świata. Pedagogika specjalna od wielu lat poszukuje sposobów urzeczywistnienia „sprawiedliwego społeczeństwa", czego szczególnym przykładem jest idea rozwoju autonomii i samosterowności osób z niepełnosprawnością oraz poszukiwanie sposobów bu-

3 Podstawą do rozważań o dwóch porządkach: czynu i rozumienia stała się interpretacja koncepcji racjonalności wg Habermasa dokonana przez R. Kwaśnicę [2016]. 
dowania struktur (społecznych) otwierających, a nie zamykających pole działania, struktur emancypacji, a nie zniewolenia" [Sadowska 2016, s. 35].

Zmianę społeczną i edukacyjną mogą inicjować i dynamizować badania o charakterze weryfikacyjnym oraz implementacyjnym. To dzięki tego typu pracom na przykład możliwa jest ocena naukowa różnorodnych tradycyjnych praktyk terapeutycznych oraz formułowanie nowych rozwiązań praktycznych. Dzięki badaniom komparatystycznym możliwy jest transfer sprawdzonych rozwiązań metodycznych i organizacyjnych. Badania w działaniu oraz badania ewaluacyjne wspierają naukową refleksją proces zmiany praktyki społecznej w tym edukacji osób z niepełnosprawnością.

\section{Kim jest współczesny pedagog specjalny - zagrożenie utraty tożsamości zawodowej}

Jeszcze do niedawna określenie roli zawodowej specjalisty posiadającego kwalifikacje z zakresu pedagogiki specjalnej było dość jednoznaczne. Kategorią tą określano zakres czynności nauczyciela szkoły specjalnej, polegających na wypełnianiu zadań opiekuńczych oraz dydaktyczno-wychowawczych, skierowanych do dzieci i uczniów z danym rodzajem i stopniem niepełnosprawności, realizowanych $\mathrm{w}$ specjalnie do tego celu stworzonej przestrzeni przedszkola, szkoły specjalnej lub specjalistycznego ośrodka o charakterze terapeutyczno-edukacyjnym. Z czasem zakres działań zawodowych pedagoga specjalnego rozszerzono także na inne formy kształcenia specjalnego realizowanego poza szkołą specjalną, w ramach edukacji integracyjnej lub włączającej. Aktualnie oczekuje się od nauczycieli posiadających kwalifikacje z zakresu pedagogiki specjalnej gotowości do podjęcia pracy edukacyjno-terapeutycznej z uczniami, których specjalne potrzeby edukacyjne wynikają z różnych rodzajów niepełnosprawności, ale i zagrożenia niedostosowaniem społecznym lub niedostosowania społecznego. Współczesny pedagog specjalny wypełnia aktywnością zawodową także przestrzeń poza edukacją szkolną, realizuje zadania zawodowe w pracy z małym dzieckiem $\mathrm{z}$ niepełnosprawnością lub zagrożonym nieprawidłowym rozwojem $\mathrm{w}$ ramach wczesnego wspomagania. Staje się ważnym podmiotem $\mathrm{w}$ działaniach prowadzących do aktywizacji zawodowej i społecznej osób dorosłych, podejmuje opiekę nad osobami z niepełnosprawnościami w wieku senioralnym. Do jego zadań należy nie tylko bezpośrednie oddziaływanie edukacyjno-terapeutyczne, ale także budowanie koalicji instytucji oraz innych podmiotów współdziałających na rzecz osób z niepełnosprawnościami, wspieranie rodziców w skuteczniejszym wypełnianiu zadań rodzicielskich i udzielanie pomocy nauczycielom szkoły ogólnodo- 
stępnej w uprzystępnianiu przestrzeni szkolnej dla uczniów z niepełnosprawnościami.

Rozwiązania prawne oraz system kształcenia pedagogów specjalnych nie w pełni nadążają za tymi nowymi zadaniami i społecznymi oczekiwaniami stawianymi wobec tej grupy zawodowej. W wielu ośrodkach akademickich kształcących kadry do pracy z uczniami, których specjalne potrzeby rozwojowe i edukacyjne wynikają z niepełnosprawności, przygotowanie do realizacji zadań zawodowych jest wyraźnie sprofilowane, przekazywana wiedza oraz kształtowane umiejętności zawodowe dotyczą uczniów z danym rodzajem i stopniem niepełnosprawności. Aktualnie kwalifikacje pedagoga specjalnego można uzyskać, kończąc studia wyższe na kierunku pedagogika lub pedagogika specjalna w zakresie odpowiednim do niepełnosprawności uczniów [Rozporządzenie MEN z dnia 1 sierpnia $2017 \mathrm{r}$. w sprawie szczegółowych kwalifikacji wymaganych od nauczycieli, Dz. U. poz. 1575]. Dodatkowym sposobem uzyskania kwalifikacji zawodowych pedagoga specjalnego jest ukończenie studiów podyplomowych, a jeszcze do niedawna także kursu kwalifikacyjnego ${ }^{4} \mathrm{~W}$ zakresie jednej z subdyscyplin pedagogiki specjalnej.

W aktualnie obowiązującym rejestrze zawodów opublikowanym w Rozporządzeniu Ministra Pracy i Polityki Społecznej z dnia 7 sierpnia 2014 r. w sprawie klasyfikacji zawodów i specjalności na potrzeby rynku pracy oraz zakresu jej stosowania [Dz.U. z 2014 r., poz. 1145] widnieje kategoria zawodowa - nauczyciele szkół specjalnych oraz wyróżnione w ramach tego zawodu specjalności: nauczyciel upośledzonych umysłowo (oligofrenopedagog), nauczyciel niesłyszących i niedosłyszących (surdopedagog) i inne. Zapisy te budzą zastrzeżenia nie tylko pod względem przestarzałej terminologii określającej podmiot pedagogicznych oddziaływań, ale też z powodu zawężania faktycznych oraz oczekiwanych kompetencji istotnych dla tych specjalistów.

W efekcie starań podjętych przez pracowników naukowych Akademii Pedagogiki Specjalnej w $2014 \mathrm{r}$. nastąpiło formalno-prawne rozszerzenie dotychczasowej grupy zawodów związanych z działaniami służącymi wspieraniu w rozwoju osób z niepełnosprawnościami. W rejestrze zawodów i specjalności opublikowanym w rozporządzeniu Ministra Pracy i Polityki Społecznej, pod pozycją 235919 umieszczono zawód - pedagog specjalny, skupiający specjalistów legitymujących się sprofilowanymi kompetencjami, ukierunkowanymi na pracę z uczniem $\mathrm{z}$ orzeczeniem o potrzebie kształcenia specjalnego [Przygotowanie nauczycieli do pracy z uczniem z niepetnosprawnościa, Forum Pedagogiki Specjalnej].

Zgodnie z założeniami autorów wniosku pedagog specjalny jest specjalistą posiadającym wiedzę i umiejętności do pracy z uczniami z różnymi rodzajami

4 Od 2016 r. nie jest możliwe uzyskanie kwalifikacji pedagoga specjalnego na podstawie kursu (zob. Dz. U. z 2016 r., poz. 1591, Rozporządzenie Ministra Edukacji Narodowej z dnia 29 września 2016 r. w sprawie placówek doskonalenia nauczycieli). 
i stopniami niepełnosprawności w przedszkolu i szkole ogólnodostępnej i integracyjnej.

Może być zatrudniony na stanowisku:

- nauczyciela - pedagoga specjalnego w przedszkolach, szkołach integracyjnych oraz w oddziałach integracyjnych zorganizowanych w przedszkolach i szkołach ogólnodostępnych;

- nauczyciela - pedagoga specjalnego w szkołach i oddziałach ogólnodostępnych, za zgodą organu prowadzącego.

W syntetycznym opisie zawodu, wymieniono następujące zadania: „Prowadzi badania nad potrzebami edukacyjnymi osób niepełnosprawnych; udziela im wsparcia i pomocy; prowadzi zajęcia dydaktyczno-wychowawcze i opiekuńcze z dziećmi i młodzieżą w przedszkolach, szkołach różnych poziomów nauczania oraz w klasach integracyjnych; realizuje procesy rewalidacji, kompensacji oraz resocjalizacji osób niepełnosprawnych" [Opis zawodu pedagog specjalny (nr 235919) - Wortal Publicznych Służb Zatrudnienia Ministerstwo Rodziny, Pracy i Polityki Społecznej].

Zmianom legislacyjnym służącym nadaniu statusu prawnego zawodowi pedagoga specjalnego towarzyszyły działania o charakterze edukacyjnym, których celem było przygotowanie specjalistów do realizacji zadań w ramach tej profesji. W ofercie edukacyjnej Akademii Pedagogiki Specjalnej znajdują się studia na kierunku pedagogika specjalna, specjalność edukacja integracyjna i włączająca, a od 2015 r. także studia podyplomowe w tym zakresie. Podobny charakter miały studia podyplomowe Wspomaganie rozwoju ucznia ze specjalnymi potrzebami edukacyjnymi w szkole ogólnodostępnej zorganizowane w roku akademickim 2011/2012 na Wydziale Pedagogicznym i Artystycznym Uniwersytetu Jana Kochanowskiego w Kielcach ${ }^{5}$.

\section{Pedagodzy specjalni w szkole ogólnodostępnej - (nie)potrzebni specjaliści}

Zgodnie z przepisami prawa oświatowego nauczyciele zatrudnieni w szkołach ogólnodostępnych mają pełne prawo do prowadzenia zajęć dydaktycznych i wychowawczych z uczniami, których specjalne potrzeby edukacyjne wynikają z niepełnosprawności bez konieczności posiadania specjalistycznego przygotowania

\footnotetext{
Na Uniwersytecie Jana Kochanowskiego w latach 2011-2012 zrealizowano studia podyplomowe Wspomaganie rozwoju ucznia ze specjalnymi potrzebami edukacyjnymi w szkole ogólnodostępnej. Studia te były jedną z form Programu „Benild - Doskonalenie Świętokrzyskich Kadr Oświatowych" współfinansowanego ze środków Unii Europejskiej w ramach Europejskiego Funduszu Społecznego.
} 
z zakresu pedagogiki specjalnej ${ }^{6}$. W tych szkołach ogólnodostępnych, w których kształceniem objęci są uczniowie posiadający orzeczenie o potrzebie kształcenia specjalnego wydane ze względu na autyzm, w tym zespół Aspergera lub niepełnosprawności sprzężone, istnieje prawny obowiązek dodatkowego zatrudniania osób wspierających kształcenie specjalne: nauczycieli posiadających kwalifikacje w zakresie pedagogiki specjalnej, specjalistów (psycholog, logopeda, pedagog, rehabilitant), asystenta nauczyciela edukacji wczesnoszkolnej, pomocy nauczyciela. Obowiązujące rozwiązania prawa oświatowego świadczą o tym, że kompetencje zatrudnianego nauczyciela, posiadającego kwalifikacje $\mathrm{w}$ zakresie pedagogiki specjalnej nie są jednak przez ustawodawcę traktowane jako na tyle istotne, by nie można ich było zastąpić kompetencjami asystenta (w klasach I-III) lub pomocy nauczyciela - od których wymaga się uwzględniania zaleceń orzeczenia o potrzebie kształcenia specjalnego. Także w przypadku uczniów, których specjalne potrzeby edukacyjne wynikają z innych niż wymienione wyżej rodzajów niepełnosprawności, za zgodą organu prowadzącego placówkę istnieje możliwość zatrudnienia dodatkowego nauczyciela z kwalifikacjami z zakresu pedagogiki specjalnej [Rozporządzenie MEN z dnia 24 lipca 2015 r. w sprawie warunków organizowania kształcenia, wychowania i opieki dla dzieci i młodzieży niepełnosprawnych, niedostosowanych społecznie i zagrożonych niedostosowaniem społecznym, Dz. U. z 2015 r., poz. 1113].

Obecni w szkole ogólnodostępnej nauczyciele posiadający kwalifikacje w zakresie pedagogiki specjalnej to najczęściej osoby, które zdobyły uprawnienia zawodowe na kursach kwalifikacyjnych, nieco rzadziej na studiach podyplomowych lub studiach kierunkowych. Tak wynika z prowadzonych badań wśród nauczycieli województwa świętokrzyskiego [Bidziński i in. 2013]. Prowadzone od wielu lat w naszym kraju kursy kwalifikacyjne, adresowane były do osób posiadających przygotowanie do wykonywania zawodu nauczyciela. Celem tych szkoleń było wyposażenie uczestników w kompetencje oraz nadanie kwalifikacji do nauczania określonego przedmiotu - prowadzenia zajęć z dziećmi i młodzieżą $\mathrm{z}$ danym rodzajem niepełnosprawności w szkołach specjalnych, integracyjnych, ogólnodostępnych oraz innych placówkach oświatowo-wychowawczych, opiekuńczych, rewalidacyjnych. Uczestnicy kursów kwalifikacyjnych, zgodnie z prawem, nie mieli obowiązku odbycia praktycznych zajęć, a ich szkolenie miało wyłącznie wymiar teoretyczny. Od wielu lat akademickie środowisko pedagogów specjalnych zgłaszało liczne zastrzeżenia co do skuteczności tej formy

6 Poddając krytycznej analizie zakres i charakter kompetencji w obecnym modelu studiów pedagogicznych/nauczycielskich Z. Janiszewska-Nieścioruk i S. Sadowska zwracają uwagę na niebezpieczeństwo deprecjonowania dorobku naukowego, badawczego i metodycznego pedagogiki specjalnej choćby z uwagi na to, iż w założeniach prawa oświatowego "to nauczyciel - po kursowym w zakresie tej problematyki "przygotowaniu” - uznawany jest za bardziej kompetentnego specjalistę od pedagoga specjalnego - absolwenta I i II stopnia studiów tego kierunku" [2016, s. 18]. 
kształcenia zawodowego, szczególną wątpliwość budził niski poziom kształcenia umiejętności praktycznych związanych z realizacją pracy edukacyjnej i terapeutycznej z uczniami z niepełnosprawnością [Gajdzica 2014]. Od kilku lat obowiązujące przepisy prawa oświatowego wyłączyły możliwość zdobywania kwalifikacji z zakresu pedagogiki specjalnej na kursach kwalifikacyjnych [Rozporządzenie MEN z dnia 12 marca 2009 r. w sprawie kwalifikacji, Dz. U. Nr 50, poz. 400]. Aktualnie jedyną drogą uzyskania statusu pedagoga specjalnego są studia licencjackie, magisterskie lub podyplomowe.

W ciągu wielu lat prowadzenia kursów kwalifikacyjnych wypromowano liczną grupę nauczycieli z kwalifikacjami z zakresu wybranej subdyscypliny pedagogiki specjalnej. Przykładowa analiza treści nauczania Ramowego programu kursu kwalifikacyjnego z zakresu oligofrenopedagogiki dla nauczycieli i wychowawców placówek dla dzieci upośledzonych umysłowo [MEN 1992], który przez wiele lat stanowił podstawę dla formułowania celów kształcenia, wskazuje na nieadekwatny do dzisiejszych potrzeb zakres wiedzy i umiejętności kształtowanych w ramach tych szkoleń. Uczestnicy kursów byli w sposób bardzo ograniczony wyposażani w kompetencje przydatne do udzielania wsparcia innym nauczycielom oraz organizowania działań środowiskowych - budowania lokalnej koalicji na rzecz ucznia i jego rodziny wśród nauczycieli, szkolnych i pozaszkolnych specjalistów zaangażowanych $\mathrm{w}$ jego rozwój. Niestety podobnie w obowiązujących standardach stanowiących podstawę planowania studiów podyplomowych kompetencje te nie są zapisane w sposób wystarczający. Brak tych kompetencji prawdopodobnie poważnie utrudnia absolwentom kursów kwalifikacyjnych realizowanie zadań na rzecz organizowania wspierającego środowiska edukacyjnego dla uczniów z orzeczeniem o potrzebie kształcenia specjalnego.

Niestety, podobnie w obowiązujących standardach kształcenia stanowiących podstawę planowania studiów podyplomowych kompetencje te nie są zapisane w sposób wystarczający.

Wielu pedagogów specjalnych $\mathrm{w}$ minionych latach było kształconych na podstawie bio-medycznego modelu niepełnosprawności. Do dzisiaj może to skutkować medykalizacją i biologicznym determinizmem w myśleniu o fenomenie ludzkiej niepełnosprawności i poważnie utrudniać dialog z innymi osobami podmiotami działań edukacyjnych, wspierających rozwój i aktywizujących. Nadal język pedagogiki specjalnej, zwłaszcza jej praktycznych realizatorów, bywa przepełniony pojęciami medycznymi, a charakterystyka osób z niepełnosprawnością dokonywana jest głównie $\mathrm{w}$ odniesieniu do jednostek chorobowych zaczerpniętych z medycznych klasyfikacji. Niestety nadal w przestrzeni edukacyjnej można usłyszeć określenia "autystyk”, „upośledzony umysłowo”, którymi specjaliści określają podmiot swoich rewalidacyjnych oddziaływań. Sposobom komunikowania o niepełnej sprawności towarzyszy także myślenie o domi- 
nującej roli procesów terapeutycznych nad innymi działaniami o charakterze edukacyjnym oraz przekonanie o konieczności specjalnego organizowania przestrzeni edukacji dla osób z niepełnosprawnością połączony z odrzuceniem lub deprecjonowaniem idei edukacji włączającej.

Podobnych trudności doświadczają nauczyciele szkół ogólnodostępnych, którzy nie czują się pełnomocni do pracy z uczniami z indywidualnymi potrzebami edukacyjnymi wynikającymi z niepełnosprawności. W głównym nurcie przygotowania zawodowego nauczycieli przez wiele lat nie zakładano konieczności wyposażenia przyszłych adeptów zawodu w kompetencje przydatne do pracy z tymi uczniami. Dopiero od niedawna w obowiązujących standardach przygotowania do zawodu nauczyciela obecne są treści z zakresu pedagogiki specjalnej, ale nadal traktowane są one dość powierzchownie. Problematyczną kwestię stanowi poziom wiedzy, umiejętności i kompetencji osiągniętych $\mathrm{w}$ realizacji modułu 2 „Przygotowanie w zakresie psychologiczno-pedagogicznym” zawartego w Rozporządzenie Ministra Nauki i Szkolnictwa Wyższego z dnia 17 stycznia 2012 r. w sprawie standardów kształcenia przygotowującego do wykonywania zawodu nauczyciela, [Dz.U. 2012 poz. 131]. Wydaje się on niewystarczający do podjęcia efektywnej pracy z uczniem ze specjalnymi potrzebami edukacyjnymi. Podobnie krytycznie określa zapisy standardów kształcenia zawarte w odrębnym module kształcenia - moduł 5. Przygotowanie w zakresie pedagogiki specjalnej Z. Janiszewska-Nieścioruk [2016, s. 52-53]. Autorka podkreśla, że moduł ten (w wymiarze 350 godz.) „"może, a więc nie musi być realizowany w ramach kierunkowego i specjalnościowego przygotowania nauczycieli". Możliwości konstruowania przez uczelnie programów studiów nauczycielskich i pedagogicznych na zasadzie uznaniowości w określaniu wymiaru praktycznego oraz metodycznego przygotowania studentów w zakresie treści modułu 5, mogą spowodować, iż poziom związanych z nimi kompetencji okaże się niewystarczający.

Problemy komunikacyjne, niedostatki w zakresie pewnych kompetencji zawodowych ${ }^{7}$, ale przede wszystkim brak pełnej zgody na realizację idei edukacji włączającej, mogą stanowić barierę w budowaniu wspólnoty nauczycieli szkół ogólnodostępnych i pedagogów specjalnych. Obok subiektywnych barier istnieje wiele obiektywnych ograniczeń w nawiązaniu dialogu i podjęciu współpracy między tymi podmiotami.

Niewielką skuteczność oraz małą dostępność wsparcia płynącego od pedagogów specjalnych do nauczycieli szkół ogólnodostępnych potwierdzają wyniki badań przeprowadzonych wśród 405 nauczycieli województwa świętokrzyskiego

\footnotetext{
W badaniach prowadzonych wśród nauczycieli województwa świętokrzyskiego konstatowano, iż badani rzadko traktowali swoje zasoby kompetencyjne jako przydatne do pracy z dziećmi, których specjalne potrzeby wynikają z niepełnosprawności sensorycznych, niepełnosprawności motorycznej lub przewlekłych chorób [Bidziński i in., 2013, s. 121-167].
} 
[Bidziński i in. 2013]. W opinii respondentów pedagog specjalny nie jest postrzegany jako ważne, dostępne i efektywne źródło wsparcia zawodowego w pracy z uczniami ze specjalnymi potrzebami edukacyjnymi. Ocena ta prawdopodobnie spowodowana jest ograniczonym zakresem wcześniejszych doświadczeń badanych nauczycieli w pozyskiwaniu wsparcia od tej grupy specjalistów.

Uzupełnieniem powyższej analizy są wnioski płynące z porównania średnich ocen w zakresie subiektywnego postrzegania własnych kompetencji diagnostycznych, planistycznych, realizacyjnych i ewaluacyjnych przez pedagogów specjalnych - nauczycieli szkoły specjalnej na tle całej ponad czterystuosobowej grupy badanych nauczycieli. Pedagodzy specjalni uczestniczący w badaniach - w większości nauczyciele szkół specjalnych dla uczniów z niepełnosprawnością intelektualną, najwyżej ocenili swoje kompetencje $\mathrm{w}$ zakresie wspomagania rozwoju uczniów, których potrzeby edukacyjne wynikają z niepełnosprawności (głównie intelektualnej), oceniając jednocześnie znacznie niżej niż cała grupa badanych kompetencje wobec uczniów, których różnorodne potrzeby edukacyjne generowane są uwarunkowaniami środowiskowymi, niedostosowaniem społecznym, zagrożeniem niedostosowaniem społecznym, sytuacją kryzysową lub traumatyczną oraz specyficznymi trudnościami w uczeniu się, a także szczególnymi zdolnościami [Rutkowski 2014, s. 49-59].

Zgodnie z obowiązującymi zapisami prawa oświatowego tradycyjnie rozumiane kompetencje specjalistyczne pedagogów specjalnych - nauczycieli szkoły specjalnej (oligofrenopedagogów, surdopedagogów, tyflopedagogów itd.) mogą być wykorzystane w przestrzeni edukacyjnej poza placówką specjalną - w szczególności $\mathrm{w}$ szkole ogólnodostępnej, przede wszystkim $\mathrm{w}$ realizacji zadania związanego z pomocą pedagogiczną konkretnemu uczniowi z niepełnosprawnością $\mathrm{w}$ ramach zajęć rewalidacyjnych. W kontekście realizowania transferu doświadczeń pedagogiki specjalnej do szerokiej przestrzeni środowiskowej sprzyjającej realizacji różnorodnych potrzeb uczniów i nauczycieli wspomniane kompetencje mogą okazać się zbyt wąskozakresowe, by efektywnie współtworzyć lokalne koalicje na rzecz ucznia i jego rodziny. W tym zakresie zawód - pedagog specjalny, zapisany z inicjatywy Akademii Pedagogiki Specjalnej w rejestrze zawodów w 2014 roku, wraz z szerokozakresowymi a jednocześnie sprofilowanymi kompetencjami, stwarza dużo większe możliwości koordynacji działań w kierunku współtworzenia przestrzeni edukacji włączającej w szkole ogólnodostępnej.

Dodatkowy problem stanowi sposób usytuowania w strukturze organizacyjnej szkoły nauczycieli z kwalifikacjami w zakresie pedagogiki specjalnej. Są to pracownicy, którzy w szkole nie są zatrudnieni na stanowisku specjalisty, lecz na etacie nauczycielskim i realizują głównie zadania dydaktyczne lub wychowawcze w ramach nauczanego przedmiotu lub prowadzonych zajęć. Nauczyciele ci posiadane kompetencje do pracy z uczniem niepełnosprawnym wykorzystują 
głównie w przestrzeni klasy, rzadziej mają sposobność do dzielenia się swoimi doświadczeniami na poziomie szkoły i wspierania innych nauczycieli w planowaniu i realizowaniu działań edukacyjnych i terapeutycznych. Coraz powszechniejsze staje się zatrudnianie w szkole ogólnodostępnej pedagogów z określonym rodzajem specjalności adekwatnym do niepełnosprawności doświadczanej przez ucznia, w celu prowadzenia zajęć rewalidacyjnych. Specjaliści ci zwykle zatrudniani są w bardzo ograniczonym wymiarze pracy (np. dwie godziny w tygodniu), przybywają do szkoły głównie w celu realizacji indywidualnych zajęć specjalistycznych z uczniami, w niedostatecznym stopniu włączani są do innych działań szkoły na rzecz uczniów ze specjalnymi potrzebami edukacyjnymi ${ }^{8}$.

Kolejną grupę specjalistów „bywających” w szkole ogólnodostępnej stanowią pracownicy poradni psychologiczno-pedagogicznej, którzy w ramach zadań statutowych mają wspierać nauczycieli w realizacji idei edukacji włączającej. Sporadyczna obecność w przestrzeni edukacyjnej zarówno specjalistów z poradni psychologiczno-pedagogicznej, jak i pedagogów specjalnych może paradoksalnie stanowić przyczynek do negatywnego naznaczania ucznia, z którym wspomniani specjaliści prowadzą zajęcia. Wśród naukowców trwa ożywiona dyskusja na temat współczesnego rozumienia działań pomocowych i terapeutycznych realizowanych $w$ ramach funkcjonowania instytucji pomocowych. Szczególnego znaczenia nabierają wysiłki demaskowania przemocy symbolicznej zawierającej się w ukrytym programie instytucji powołanych do udzielania pomocy i wspierania rozwoju. Współcześni badacze wskazują potencjalne miejsca ujawniania się przemocy symbolicznej. Są to: procedury, sytuacja przymusu, ocenianie (testowanie), przestrzeń, działania rutynowe, metody pracy, komunikacja werbalna i niewerbalna. Problem ten dotyczy nie tylko poradni jako instytucji, ale także może ujawniać się w szkole na styku specjalista i nauczyciel [Skałbania, Gretkowski 2016].

\section{Podsumowanie}

Szkoła ogólnodostępna staje się coraz częściej przestrzenią spotkania nauczycieli oraz specjalistów posiadających różnorodne kwalifikacje w zakresie pedagogiki specjalnej. To, w jakim stopniu pedagodzy specjalni włączą się aktywnie w kreowanie tej przestrzeni, zależy od wielu bardzo różnorodnych czynników, zarówno o charakterze obiektywnym jak i subiektywnym.

\footnotetext{
8 Wnioski na podstawie badań terenowych prowadzonych aktualnie przez K. Bidzińskiego w ramach projektu "Szkoła podstawowa jako wspólnota działania oraz subiektywnych i intersubiektywnych znaczeń podmiotów kreujących przestrzeń realizacji specjalnych potrzeb edukacyjnych uczniów".
} 
Wśród czynników, które mogą pozytywnie wpływać na przebieg współdziałania nauczycieli szkół ogólnodostępnych i specjalistów szczególne miejsce zajmują uregulowania prawne precyzyjnie określające ramy organizacyjne i finansowe tej współpracy. To one w sposób istotny determinują, między innymi, charakter i częstotliwość spotkań partnerów podejmujących wysiłki na rzecz tworzenia optymalnych warunków dla rozwoju uczniów ze specjalnymi potrzebami edukacyjnymi. W obowiązujących aktualnie rozwiązaniach prawnych nie określono precyzyjnie statusu pedagoga specjalnego, jego zawodowej roli ani wymogu jego obligatoryjnej obecności w przestrzeni szkoły ogólnodostępnej, w której realizują zadania uczniowie $\mathrm{z}$ niepełnosprawnością. W praktyce, zatrudnianie pedagoga specjalnego w szkole ogólnodostępnej ma nadal charakter fakultatywny i uzależnione jest od woli organu prowadzącego szkołę. W wielu szkołach nie zatrudnia się tego typu specjalistów lub wymiar ich zatrudnienia jest niewystarczający.

Zapisy prawa oświatowego zobowiązują pedagogów specjalnych zatrudnionych w szkołach specjalnych, specjalnych ośrodkach szkolno-wychowawczych, młodzieżowych ośrodkach wychowawczych i młodzieżowych ośrodkach socjoterapii, ale także pracowników poradni psychologiczno-pedagogicznych, ośrodków doradztwa i doskonalenia nauczycieli do podejmowania zadań służących wspieraniu nauczycieli szkół ogólnodostępnych w realizacji idei edukacji włączającej. Do zadań tych zaliczono między innymi obowiązek wsparcia w zakresie diagnozowania i rozwiązywania problemów dydaktyczno-wychowawczych uczniów z niepełnosprawnością, niedostosowaniem społecznym lub zagrożonych takim niedostosowaniem. Nową kategorię statutowych zadań poradni psychologiczno-pedagogicznej stanowi wspomaganie przedszkoli, szkół i placówek w zakresie realizacji zadań dydaktycznych, wychowawczych i opiekunczych. Ma ono być realizowane poprzez: rozpoznawanie potrzeb tych instytucji, ustalenie sposobów działania prowadzących do zaspokojenia tych potrzeb, zaplanowanie form wspomagania i ich realizację, wspólną ocenę efektów i opracowanie wniosków z realizacji zaplanowanych form wspomagania. Wspomaganie to polega na zaplanowaniu i przeprowadzeniu działań mających na celu poprawę jakości pracy przedszkola, szkoły lub placówki. [Rozporządzenie MEN z dnia 25 sierpnia 2017 r. zmieniające rozporządzenie w sprawie szczegółowych zasad działania publicznych poradni psychologiczno-pedagogicznych, $\mathrm{w}$ tym publicznych poradni specjalistycznych, Dz. U., poz. 1647]. Niestety są to dość ogólnikowe przepisy o charakterze deklaratywnym. Brakuje rozwiązań szczegółowych dotyczących warunków realizacji tych zadań, zwłaszcza ram organizacyjnych oraz źródeł i sposobów ich finansowania.

Podstawą skuteczności współpracy nauczycieli oraz specjalistów z zakresu pedagogiki specjalnej jest gotowość partnerów do podejmowania wspólnych 
działań na rzecz edukacyjnej inkluzji uczniów z niepełnosprawnością. Jak wynika z badań prezentowanych powyżej [Bidziński i in. 2013], nauczyciele szkół ogólnodostępnych nie zawsze oczekują na wsparcie płynące od pedagogów specjalnych, nisko oceniają dostępność i efektywność tej formy zawodowego wsparcia. Trudno jednoznacznie określić, co jest tego przyczyną, można założyć, że jedną z nich jest brak satysfakcjonujących doświadczeń obu stron. Poważny problem stanowić mogą niewystarczające zasoby kompetencyjne, które wynikają z niedostatków w przygotowaniu zawodowym.

Warunkiem skutecznej wspólpracy jest duża otwartość nauczycieli w komunikowaniu o napotykanych trudnościach zawodowych. Autorzy cytowanej monografii [Bidziński i in. 2013] stwierdzili, że stosunkowo duża grupa badanych nauczycieli szkół ogólnodostępnych zadeklarowała, że nie odczuwa choćby niewielkich trudności w tak złożonym procesie, jakim jest wspieranie uczniów w realizacji specjalnych potrzeb edukacyjnych. Próbowano wyjaśnić przyczyny tego zjawiska. Przyjęto między innymi, że pewna grupa badanych nauczycieli nie uświadamia sobie własnych trudności bądź nawet w badaniach nie chce się do nich przyznać z obawy, że może to być odebrane jako brak profesjonalizmu. Przypuszczenia te wymagają jednak dalszych weryfikacji.

Podstawą skutecznej współpracy jest sprawne porozumiewanie się partnerów, posługiwanie się zrozumiałym dla wszystkich językiem dyscypliny. Jest to warunek, który powala skutecznie prezentować swoje intencje i potrzeby. Język edukacji włączającej musi być wolny od dyskryminacyjnych praktyk stygmatyzacji. Problemem jest odmienne nadawanie znaczeń fenomenowi ludzkiej niepełnosprawności. Wciąż obecny w społecznej świadomości model medyczny determinuje nie tylko sposób komunikowania o niepełnosprawności, ale także generuje negatywne postawy [Kirenko 2007].

Mimo teoretycznego przewrotu w myśleniu o niepełnosprawności, w świadomości społecznej, w tym także w poglądach nauczycieli, nadal obecny jest tradycyjny -medyczny opis tego zjawiska. „Podejście to było/jest wyznaczane przez myślenie o niepełnosprawności w kontekście medykalizacji indywidualnego deficytu, braku, jako pochodnej funkcjonalnych ograniczeń czy psychologicznych strat (medyczny/indywidualny model niepełnosprawności). (...) Tak ujęta niepełnosprawność wymaga działań naprawczych $\mathrm{w}$ formie rehabilitacji ufundowanej na „ideologii normalności”, wzmaga potrzebę upodabniania, dorównywania odmienności do normy" [Krzemińska, Rzedzicka 2009, s. 118].

Przyjęcie przez nauczycieli tego modelu może mieć negatywny wpływ na wspólnie tworzony z innymi osobami dyskurs niepełnosprawności. Prowadzi do nadmiernej koncentracji na inności rozwojowej dziecka i zbyt mocnego akcentowania jego problemów, myślenia o niepełnosprawności głównie jako "tragedii osobistej", oraz przekonania o konieczności uruchomienia działań naprawczych 
prowadzących do korygowania dziecięcej „niedoskonałości”, zawłaszczenie zabiegami terapeutycznymi niemal całej przestrzeni dziecięcego świata [Bidziński 2016].

\section{Propozycje rozwiązań - wskazania dla teorii i praktyki}

Na podstawie przeprowadzonej analizy wydaje się zasadne sformułowanie kilku wskazań, których uwzględnienie, naszym zdaniem, może przyczynić się do optymalizacji przestrzeni spotkania kreatorów i realizatorów edukacji włączającej.

- Zwiększenie zaangażowania świata nauki w urzeczywistnianie idei „Szkoły dla wszystkich", poprzez dostarczenie dowodów naukowych dla kształtowania polityki i realizacji praktyki edukacyjnej. Służyć temu mogą prowadzone na większą niż dotychczas skalę badania stosowane, projektowe, badania w działaniu, badania ewaluacyjne.

- Krytyczna ocena dotychczasowego dorobku pedagogiki specjalnej jako nauki oraz jej dorobku metodycznego oraz postulowanych rozwiązań organizacyjnych.

- Rezygnacja przez pedagogów specjalnych z tradycyjnego modelu medycznego podczas opisywania fenomenu niepełnosprawności oraz osadzenie budowanej teorii i wynikającej z niej praktyki na paradygmacie humanistycznym, zwłaszcza subparadygmacie społecznym i tworzących go teoretycznych modelach: normalizacyjnym i upełnomocnienia.

- Uznanie, że nie da się opisywać złożonych zjawisk społecznych i niepowtarzalności losów osoby ludzkiej, odwołując się jedynie do racjonalności instrumentalnej. We współczesnej pedagogice specjalnej szczególnego znaczenia nabiera refleksja hermeneutyczna i fenomenologiczny wgląd w świat ludzkich sensów i nadawanych znaczeń oraz próba ich jakościowych analiz/rekonstrukcji, także w odniesieniu do analizy sytuacji osób doświadczających niepełnosprawności.

- Uwolnienie dyskursu o edukacji, w tym szczególnie problematyki edukacji włączającej od "dominacji rozumu instrumentalnego", na rzecz heurystycznego interpretowania zjawisk.

- Zaangażowanie się nauczycieli i specjalistów z zakresu pedagogiki specjalnej $\mathrm{w}$ dzieło tworzenia $\mathrm{w}$ przestrzeni edukacji wspólnoty działania i wspólnoty podzielanych sensów. Kluczową rolę w tym dziele odgrywa komunikacja, która polega nie tylko na skutecznym przekazywaniu informacji, ale także budowanie swoistej wspólnoty uznawanych wartości i norm oraz budowanie na ich podstawie podmiotowych relacji. 
- Wspieranie oddolnych procesów rozwoju organizacyjnego szkoły jako organizacji uczącej się oraz doskonalenie procesu zrządzania wiedzą (rola ewaluacji wewnętrznej w rozwoju organizacyjnym szkoły).

- Podjęcie działań na rzecz dalszej profesjonalizacji zawodu nauczyciela oraz pedagoga specjalnego z uwzględnieniem nowych zadań współczesnej edukacji - poprzez nowoczesny sposób przygotowania kadr oraz system doskonalenia i doradztwa zawodowego.

- Upowszechnianie wiedzy, kształtowanie umiejętności i rozwijanie kompetencji realizatorów idei edukacji włączającej w zakresie standardowych założeń uniwersalnego projektowania nauczania/uczenia się (UDL). Ich zastosowanie i konsekwentna realizacja w przestrzeni edukacji poprzez: tworzenie warunków dla optymalnej percepcji informacji, zapewnianie możliwości korzystania z adekwatnego dla ucznia kodu językowego, elastyczne i przystępne strategie konstruowania przez ucznia systemu wiedzy, itp. Umocowanie prawne UDL w dokumentach prawa oświatowego.

Wydaje się, że po spełnieniu tych warunków pedagogika specjalna ze swoim dorobkiem teoretycznym i praktycznym może $\mathrm{w}$ większym stopniu niż dotychczas, stać się źródłem wartościowych inspiracji dla nauczycieli szkół ogólnodostępnych rozwiązujących problemy wynikające $z$ indywidualnych potrzeb rozwojowych i edukacyjnych uczniów z niepełnosprawnością. Także pedagodzy specjalni, zarówno teoretycy jak i praktycy, mogą jeszcze aktywniej włączyć się w urzeczywistnianie idei edukacji włączającej.

\section{Bibliografia}

Bidziński K. (2016), Kompetencje komunikacyjne nauczycieli szkót ogólnodostępnych podstawą realizacji idei edukacji włączającej [w:] Komunikacja w przestrzeni edukacyjnej, red. E. Męcina-Bednarek, Oficyna Wydawnicza Staropolskiej Szkoły Wyższej w Kielcach, Kielce.

Bidziński K., Giermakowska A., Ozga A., Rutkowski M. (2013), Nauczyciele województwa świętokrzyskiego wobec zadań związanych z realizacja specjalnych potrzeb edukacyjnych uczniów, Wydawnictwo Uniwersytetu Jana Kochanowskiego, Kielce.

Błaszak M., Przybylski Ł. (2010), Rzeczy sa dla ludzi. Niepetnosprawność i idea uniwersalnego projektowania, Wydawnictwo Naukowe Scholar, Warszawa.

Bowe F.G. (2000), Universal Design in Education. Teaching Nontraditional Students, Bergin \& Garvey, Westport, Connecticut-London.

Budny J. (2004), Projektowanie dla wszystkich, Stowarzyszenie Przyjaciół Integracji, Warszawa.

CAST (2011), Universal Design for Learning Guidelines version 2.0. Transforming Education through Universal Design for Learning, http://www.udlcenter.org/aboutudl/udlguidelines [dostęp: 30.05.2017].

Chrzanowska I. (2015), Pedagogika specjalna. Od tradycji do wspótczesności, Oficyna Wydawnicza „Impuls”, Kraków. 
Deklaracja z Salamanki (1994), http://rownosc.info/media/uploads/deklaracja_z_salamanki.pdf [dostęp: 22.03.2015].

Dymara B. (1998), Przestrzenie szkoły i przestrzenie życia, czyli trzy światy dziecka [w:] Dziecko w świecie szkoty, red. B. Dymara, Oficyna Wydawnicza „Impuls”, Kraków.

Edukacja dla Wszystkich Education for All (1990) - opis programu, http://www.unesco.pl/edukacja/edukacja-dla-wszystkich/ [dostęp: 25.09.2015].

Gajdzica Z. (2014), Kogo najchętniej zatrudnię - czyli o oczekiwaniach dyrektorów szkót specjalnych i integracyjnych wobec absolwentów pedagogiki i pedagogiki specjalnej, „Studia Pedagogiczne”, t. LXVII.

International classification of functioning, disability and health: children \& youth version: ICF-CY (2007), http://apps.who.int/iris/bitstream/10665/43737/1/9789241547321_eng.pdf [dostęp: 12.03.2015].

Janiszewska-Nieścioruk Z. (2016), (Nie)dojrzałość proinkluzyjnych zmian w kształceniu osób z niepetnosprawnościa, "Niepełnosprawność. Dyskursy Pedagogiki Specjalnej”, nr 22, s. $47-59$.

Janiszewska-Nieścioruk Z., Sadowska S. (2016), Problemy związane z probolońskim kształceniem pedagogów i nauczycieli w Polsce, „Niepełnosprawność. Dyskursy Pedagogiki Specjalnej", nr 23, s. 13-31.

Kirenko J. (2007), Indywidualna i społeczna percepcja niepetnosprawności, Wydawnictwo UMCS, Lublin.

Konwencja o Prawach Osób Niepełnosprawnych (2006), https://www.rpo.gov.pl/pl/ konwencja-o-prawach-osob-niepelnosprawnych [dostęp: 20.05.2017].

Krause A. (2010), Wspótczesne paradygmaty pedagogiki specjalnej, Oficyna Wydawnicza „Impuls", Kraków.

Krause A. (2013a), Teoretyczne inspiracje pedagogiki specjalnej-pedagogika krytyczna, „Studia Edukacyjne", nr 25, s. 7-16.

Krause A. (2013b), Teoretyczne inspiracje pedagogiki specjalnej - pedagogika emancypacyjna, „Studia Edukacyjne", nr 28, s. 6-15.

Krzemińska D., Rzedzicka K.D. (2009), O przygotowaniu zawodowym pedagogów specjalnych krajobraz (bez) zmian?, "Niepełnosprawność”, nr 1, s. 113-123..

Kubinowski D. (2010), Jakościowe badania pedagogiczne. Filozofia - Metodyka - Ewaluacja, Wydawnictwo Uniwersytetu M. Curie-Skłodowskiej, Lublin.

Kwaśnica R. (2014), Dyskurs edukacyjny po inwazji rozumu instrumentalnego. O potrzebie refleksyjności, Wydawnictwo Dolnośląskiej Szkoły Wyższej, Wrocław.

Majewski T. (1995), Rehabilitacja zawodowa osób niepetnosprawnych, Wydawnictwo CBRRON, Warszawa.

Międzynarodowa Klasyfikacja Funkcjonowania Niepełnosprawności i Zdrowia ICF - wersja w języku polskim (2009), http://www.csioz.gov.pl/fileadmin/user_upload/Wytyczne/statystyka/icf_polish_version_56a8f7984213a.pdf [dostęp: 12.03.2015]

Nalaskowski A. (2002), Przestrzeń i miejsce szkoty, Oficyna Wydawnicza „Impuls”, Kraków. Opis zawodu pedagog specjalny (nr 235919) Wortal Publicznych Służb Zatrudnienia Ministerstwo Rodziny, Pracy i Polityki Społecznej, http://psz.praca.gov.pl/rynek-pracy/ bazy-danych/klasyfikacja-zawodow-i-specjalnosci/wyszukiwarka-opisow-zawodow//-/ 
klasyfikacja_zawodow/zawod/235919?_jobclassificationportlet_WAR_nnkportlet_back Url=http [dostęp: 12.03.2015].

Pilecka W. (2011), Psychologia zdrowia dzieci i młodzieży jako dyscyplina stosowana [w:] Psychologia zdrowia dzieci i młodzieży. Perspektywa kliniczna, red. W. Pilecka, Wydawnictwo Uniwersytetu Jagiellońskiego, Kraków.

Przygotowanie nauczycieli do pracy z uczniem z niepełnosprawnością, Forum Pedagogiki Specjalnej, http://www.efps.pl/pl/2013-06-03-18-19-54/zawod-pedagog-specjalny/item/ 490-przygotowanie-nauczycieli-do-pracy-z-uczeniem-z-niepelnosprawnoscia-aktualnystan [dostęp: 12.03.2015].

Ramowy program kursu Oligofrenopedagogiki MEN (1992), http://okko.edu.pl/wp-content/uploads/2012/09/szczeg.-plan-kursu-oligo.pdf [dostęp: 12.03.2015].

Rozporządzenie MEN z dnia 1 sierpnia 2017 r. w sprawie szczegółowych kwalifikacji wymaganych od nauczycieli (Dz. U., poz. 1575)

Rozporządzenie Ministra Edukacji Narodowej z dnia 24 lipca 2015 r. w sprawie warunków organizowania kształcenia, wychowania i opieki dla dzieci i młodzieży niepełnosprawnych, niedostosowanych społecznie i zagrożonych niedostosowaniem społecznym (Dz. U. z 2015 r., poz. 1113).

Rozporządzenie Ministra Nauki i Szkolnictwa Wyższego z dnia 17 stycznia 2012 r. w sprawie standardów kształcenia przygotowującego do wykonywania zawodu nauczyciela (Dz. U. z 2012 r., poz. 131).

Rozporządzenie Ministra Pracy i Polityki Społecznej z dnia 7 sierpnia 2014 r. w sprawie klasyfikacji zawodów i specjalności na potrzeby rynku pracy oraz zakresu jej stosowania (Dz. U. z 2014 r., poz. 1145).

Rutkowski M. (2013), Niepetnosprawność w edukacji - nowe konteksty: przestrzen - relacje komunikacja, [w:] Problematyka niepełnosprawności w mediach i edukacji, red. E. Jaska, T. Skoczek, Wydawnictwo SGGW, Warszawa.

Rutkowski M. (2014), Kompetencje diagnostyczne, planistyczne, realizacyjne i ewaluacyjne w pracy z uczniami ze specjalnymi potrzebami edukacyjnymi - w ocenie własnej nauczycieli uczacych w placówkach specjalnych oraz integracyjnych, „Pedagogika. Badania, dyskusje, otwarcia. Dzieci i młodzież ze specjalnymi potrzebami edukacyjnymi. Implikacje dla teorii i praktyki", z. 3, s. 49-59.

Sadowska S. (2016), Kim powinien być pedagog specjalny: granice wzorca w kontekście potrzeb zmiany społecznej i horyzont "odpowiedzi" rozbieżnych, "Niepełnosprawność. Dyskursy Pedagogiki Specjalnej", nr 23, s. 32-47.

Skałbania B, Gretkowski A. (2016), Przemoc symboliczna w instytucji pomocowej - paradoksy pomagania, "Roczniki Teologiczne”, t. LXIII, z. 1, s. 121-137.

Standardowe Zasady Wyrównywania Szans Osób Niepełnosprawnych (1990), http://www. tus.org.pl/uploads/dokumenty/standardowe_zasady_wyrownywania_szans_osob_ niepelnosprawnychpdf [dostęp: 22.03.2015].

Surina I. (2012), Rozważania o przestrzeni edukacyjnej - od teorii do praktyki edukacyjnej [w:] Przestrzeń edukacyjna wobec wyzwań wspótczesności, red. I. Surina, Oficyna Wydawnicza „Impuls", Kraków.

Szluz B. (2007), Osoby niepetnosprawne w Unii Europejskiej - sytuacja i perspektywy, „Seminare Poszukiwanie Naukowe", nr 24, s. 325-337. 
Üstün T.B. (1999), Międzynarodowa Klasyfikacja Uszkodzeń, Niepetnosprawności i UczestnictwaICIDH-2, Wydawnictwo Polskie Stowarzyszenie na Rzecz Osób z Upośledzeniem Umysłowym, Warszawa.

Wiliński M. (2010), Modele niepetnosprawności: indywidualny - funkcjonalny - społeczny [w:] Diagnoza potrzeb i modele pomocy dla osób z niepetnosprawnościami, red. A. Brzezińska, R. Kaczan, K. Smoczyńska, Wydawnictwo Naukowe Scholar, Warszawa.

Witkowski T. (2009), Zakazana psychologia, Wydawnictwo Moderator, Wrocław.

Woźniak Z. (2008), Niepetnosprawność i niepetnosprawni w polityce społecznej. Społeczny kontekst medycznego problemu, Academica Wydawnictwo SWPS, Warszawa. 